\title{
Morphometric study of Phragmatopoma caudata (Polychaeta: Sabellida: Sabellariidae)
}

\author{
Gisele E. Occhioni ${ }^{1,2}$; Ana C. S. Brasil ${ }^{1} \&$ Alexandre F. B. Araújo ${ }^{1}$
}

\author{
${ }^{1}$ Departamento de Biologia Animal, Instituto de Biologia, Universidade Federal Rural do Rio de Janeiro. Rodovia BR 465, km \\ 7, Caixa Postal 74524, 23851-970 Seropédica, Rio de Janeiro, Brasil. \\ 2 Corresponding author. E-mail: gicaocchio@yahoo.com.br
}

\begin{abstract}
The sabellariid Phragmatopoma caudata (Kroyer, 1856), Morch, 1863 is widely distributed in the Americas and constructs large reef agglomerates that provide substrates for other benthic species. However, the difficulty in obtaining size data (especially length) hampers population studies, making it necessary to carry out morphometric studies as basis for studies of population dynamics. The objective of the present study is to determine the best morphological descriptor of length in P. caudata. A total of 17 morphometric variables were measured in specimens from four different populations. Measurements were performed using an ocular micrometer attached to a stereoscopic microscope. Correlations in the dataset were tested using Pearson's linear correlation coefficient, and the hypothesis of morphometric differences among populations was tested using MANOVA and principal component analysis. Correlation coefficients were different amongst populations, as well as in the measured traits. Moreover, the results suggest that populations differ more strongly in body size than in shape. Although populations presented different morphometric relationships, the length of the first thoracic chaetiger was one of the variables with highest correlation with total length. This result, as well as the fact that such region is located on the anterior portion of the body, suggests that this structure is a good length descriptor in $P$. caudata.
\end{abstract}

KEY WORDS. Annelida; Brazilian Coast; Correlation; Polychaete.

Polychaetes are among the most important benthic macrofaunal groups due to their dominance and contribution to the number of species and individuals, productivity, biomass, and energy flow (KNox 1977, Amaral et al. 1994, Maccord \& Amaral 2005). Nevertheless, knowledge on polychaete population ecology is limited to only a few species. Difficulties limiting studies on polychaete population dynamics include factors such as the rupture and the elasticity of the specimens during collection and fixation process (Yokoyama 1988, SeITz \& SCHAFFNER 1995). A common technique to determine their ageclass is the use of measurements of body structures/regions to describe individual size variation along temporal studies, which requires the search for morphological measures that describe more reliably size variation when total length cannot be used (Desrosiers et al. 1988). The parameters used normally are the width or length of different chaetigers or segments, length of anterior region, length or width of prostomium, bucal appendages, and particularly rigid structures when these are present (Chambers \& Milne 1975, Gillet 1990, Fauchald 1991).

Meristic variables, such as the total number of chaetigers, have been used in polychaete morphometric studies, when this variable is correlated to width and length of specific chaetigers, as in the study of Streptosyllis verrilli (Moore, 1907) by SARDÁ \& MARTIN (1993). FAUCHALD (1991), investigating eunicids, also com- pared the total number of chaetigers against length and total volume. Other studies compared length and width parameters against dry weight of the specimen, for instance in Nereis virens (Sars, 1835) and Nepthys caeca (Fabricius, 1780) (CARON et al. 1995), and in Loimia medusa (Savingy, 1818) (Seitz \& SChafFner 1995). Similarly, studies on the population dynamics of Nereis diversicolor (Muller, 1776) (GILlet 1990) and Laeonereis acuta (Treadwell, 1923) (OMENA \& AMARAL 2000, 2001) correlated parameters such as width and length of some chaetigers with total length.

Sabellariidae is composed of two subfamilies that include 12 genera with approximately 111 species (KIRTLEy 1994). These organisms inhabit shallow to deep regions, are strictly sedentary and use sand particles with a mucous-proteic cement to construct their dwelling tubes. Representatives of this family are sensitive to oil spill and suffer body deformation, which could be monitored in population dynamics studies overtime scales, although previous morphometric studies would be required (Zale \& MerRifield 1989).

The body of Phragmatopoma caudata (Kroyer, 1856), Morch, 1863 is divided into five regions: peduncle and opercular crown; the thorax, formed by the fusion of peduncle, opercular crown and the first two chaetigers the parathorax that consists of three chaetigers; the abdomen; and a caudal region, which is formed from a fusion of the last chaetigers. Specimens may reach 17 
$\mathrm{mm}$ in length and the opercular crown is formed by three distinct series of paleae (Amaral 1987, KirtLey 1994). This species has a wide distribution in the Americas, occurring from Cape Canaveral in the U.S.A. to the state of Santa Catarina, in Brazil. Considering that an extensive geographical distribution may be associated with a complex of morphologically similar species and that sabellariids are constructors of large reef aggregates which serve as substrates to other species, it is crucial to study the population dynamics of the present species. However, obtaining data on size and age-class distribution is difficult in these organisms, and it is an impossible task to be accomplished without previous investigations on the variables correlated to total length. Hence, to enable future population studies, the main objective of the present study was to determine the best morphological measure to describe the total length of $P$. caudata by comparing different populations.

\section{MATERIAL AND METHODS}

The present study was based on previously collected material from four regions of the Brazilian coastline. In each region, 30 specimens were selected, for a total of 120 examined individuals. The study comprised two populations from the state of Rio de Janeiro: Praia Grande, in Ilha da Marambaia (1), and Ibicuí, in Mangaratiba (2); one population from state of São Paulo: Praia da Fazenda in Ubatuba, Project Biota -Fapesp (3); and one population from state of Paraná: Praia da Gruta, Ilha do Mel (4) (Fig. 1). Only individuals from population 4 were anesthetized after collection. A total of 17 morphometric measurements were obtained using an ocular micrometer attached to a stereoscopic microscope (Tab. I and Figs 2-5). For each specimen, the mean of three paleae of each series was used as one of the parameters (Figs 6-8). Chaetae were mounted on permanent slides using Gray \& Wess (PVA) (Humason 1979) and the specimens were maintained in individually labelled vials for reference.

Table I. Measurements obtained in each portion of the body of $P$. caudata for the morphometric study.

\begin{tabular}{|c|c|}
\hline Structures & Measurements \\
\hline \multirow[t]{2}{*}{ Thorax } & Total length \\
\hline & Length and width of first setiger \\
\hline \multirow[t]{2}{*}{ Parathorax } & Total length \\
\hline & Length and width of median setiger \\
\hline \multirow[t]{2}{*}{ Abdomen } & Total length \\
\hline & Length and width of first setiger \\
\hline Caudal region & Total length \\
\hline Opercular crown & Diameter 1 and 2 \\
\hline \multirow[t]{3}{*}{ Paleae } & Length of the outer \\
\hline & Length and width of the middle \\
\hline & Length and width of the inner \\
\hline
\end{tabular}

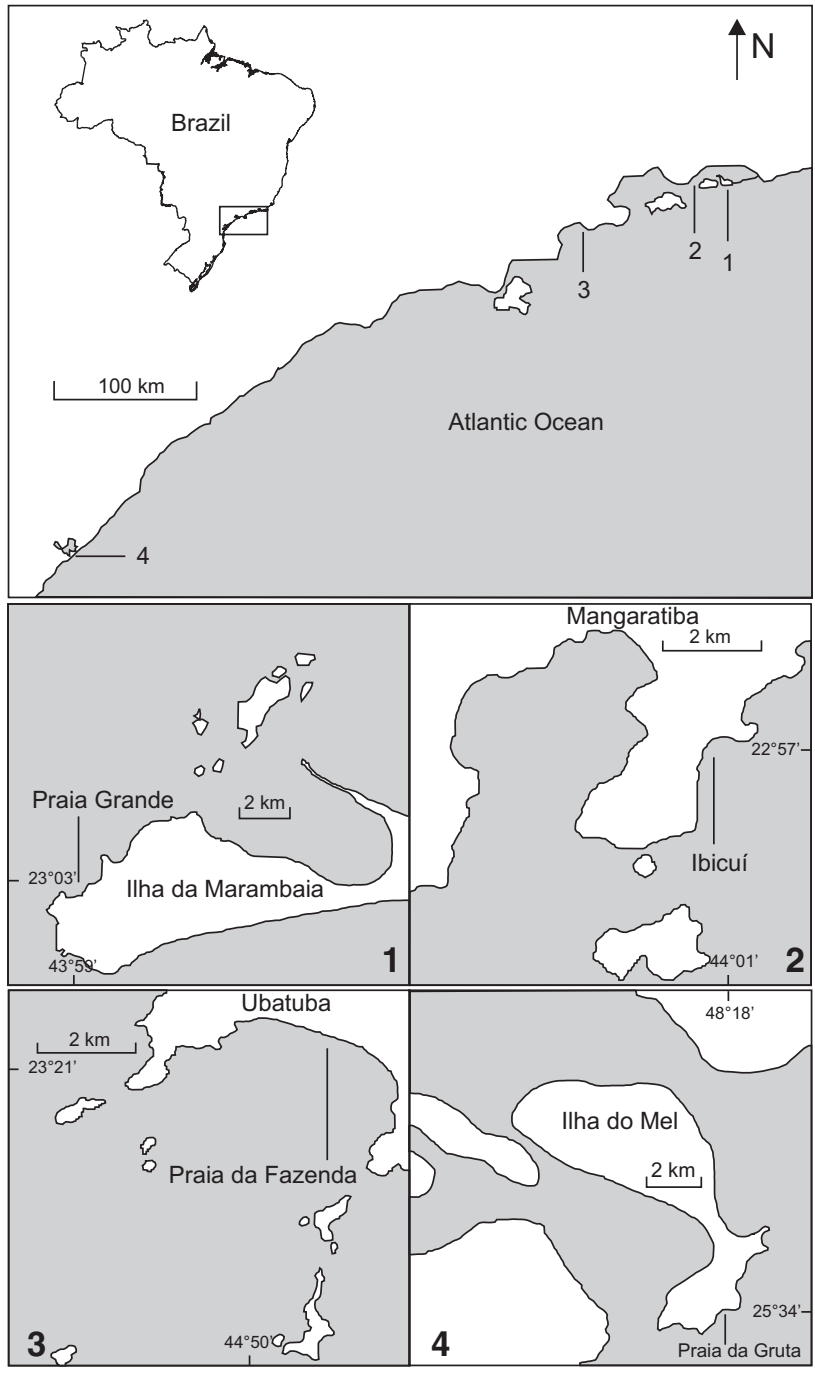

Figure 1. Location of the study area: (1) Praia Grande, Ilha da Marambaia, Rio de Janeiro State; (2) Ibicuí, Mangaratiba, Rio de Janeiro State; (3) Praia da Fazenda, Ubatuba, São Paulo State; (4) Praia da Gruta, Ilha do Mel, Paraná State.

Measurements were converted to millimetres and logtransformed. Normality was tested using a t-test (one-sample) at $95 \%$ confidence level for each variable and locality. After assessing departures from normality, variables were analysed by Pearson's correlation tests (VIEIRA 1991) to determine which variables had the highest correlation with total length. The same statistical analysis applied to individual populations was carried out to all the specimens.

A multivariate analysis of variance (MANOVA) was used initially to test the hypothesis of morphometric differences among populations. Subsequently, a principal component analysis (PCA) of the covariance matrix of all variables - was per- 


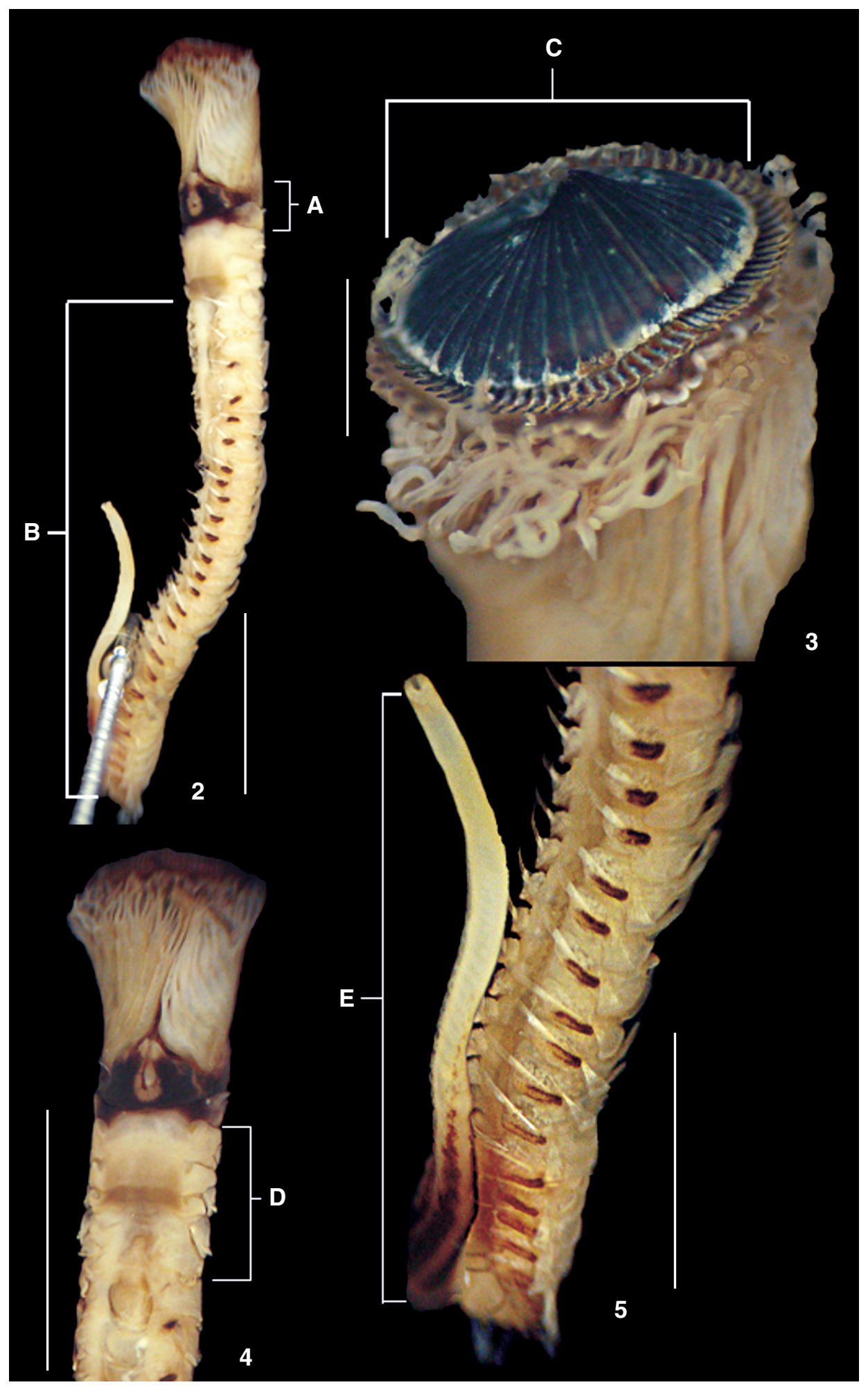

Figures 2-5. Phragmatopoma caudata: (2) body; (3) peduncle and opercular crown; (4) anterior region; (5) posterior region. (A) thorax, (B) abdomen, (C) opercular crown, (D) parathorax, (E) caudal region. Scale: (2) $10 \mathrm{~mm}$, (3) $1 \mathrm{~mm}$, (4) $5 \mathrm{~mm}$, (5) $5 \mathrm{~mm}$. 


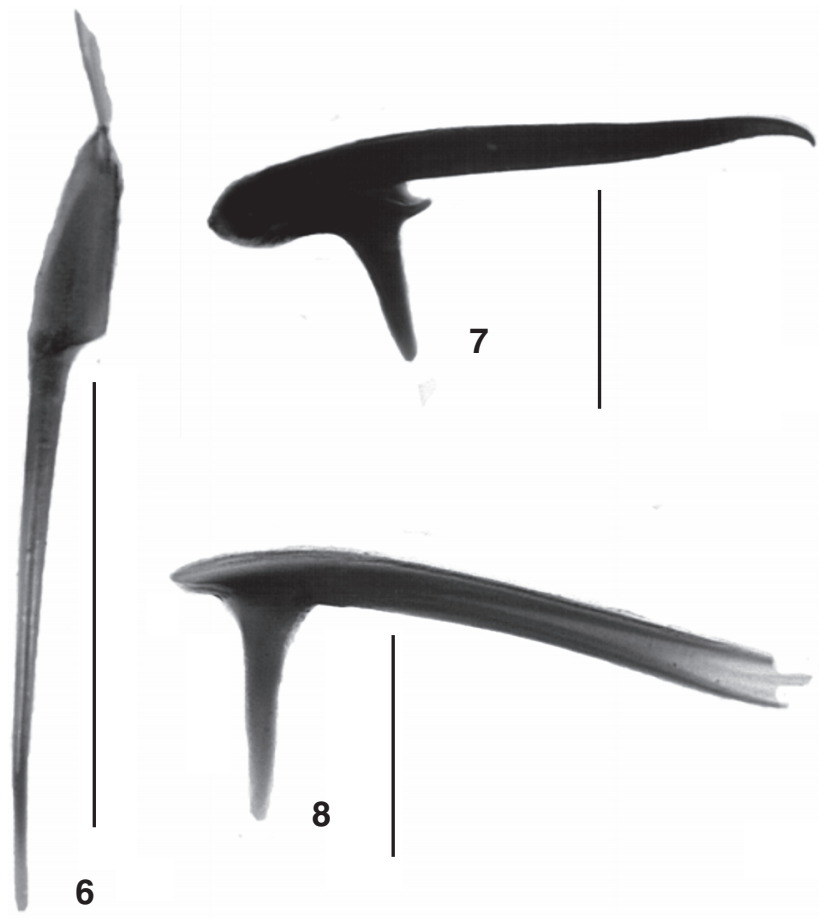

Figures 6-8. Paleae: (6) outer palea; (7) middle palea; (8) inner palea. Scale: $0,25 \mathrm{~mm}$.

formed to ordinate the data and to visualise possible differences between populations. Results from the first two components were tested using a discriminant analysis. All statistical analyses were performed using the statistical software SYSTAT 8.0.

\section{RESULTS}

The log-transformed values of the measurements showed a normal distribution which was confirmed by the t-test (SoKAL $\&$ RohlF 1995). The correlation coefficients of total length and the measurements of the structures are shown in table II, together with their respective significance values. Significant values were observed for abdominal length in population 1 ; abdominal, caudal and thoracic length in population 2; abdominal, caudal, first thoracic chaetiger and outer palea length in population 4 , in which the first three measurements had the highest correlation values. In population 3, the highest correlation coefficients were thoracic length, abdominal length and first abdominal chaetiger length. Furthermore, the following measurements also presented significant values: parathorax length, caudal length, first thoracic chaetiger length and outer palea length (Tab. II).

When all populations were analysed together, only the width of the parathoracic median chaetiger, the width of first thoracic chaetiger and width of the first abdominal chaetiger did not correlate significantly with body length. The highest coefficients were observed for abdominal length, caudal length, first thoracic chaetiger length, and thoracic length (Tab. II).

Morphometric variation was significantly different amongst the four studied populations (MANOVA, Wilks' $\lambda=0.013$, F statistic $=18.077, \mathrm{df}=54295, \mathrm{p}<=0.0001)$, a result that was corroborated by the PCA. The scores of the populations in the first two principal components were used in a discriminant analysis and the result was highly significant (Wilks' $\lambda=0.2080, \mathrm{df}=23116, \mathrm{p}=<0.0001)$. The principal components and their corresponding variances are shown in table III. The graphical representation of the PCA indicates that the population of Ibicuí is different in size (component 1) and shape (component 2) when compared to populations from other localities (Fig. 9). Given that PC1 explained more than 51\% of the variation in the dataset and that most loadings were positive, one can infer that it represents size (only the variable "width of the parathoracic median chaetiger" showed negative loading, although weakly). The PC2, however, presented positive and negative loadings, which suggests differences in shape (allometric component) (Elstrott \& Irschick 2004, França et al. 2008). The loadings from the PC2 (accounting for less than 15\% of total variance) are more dissimilar amongst themselves compared to the first component. These results suggest that the body size has higher influence than shape in the studied populations.

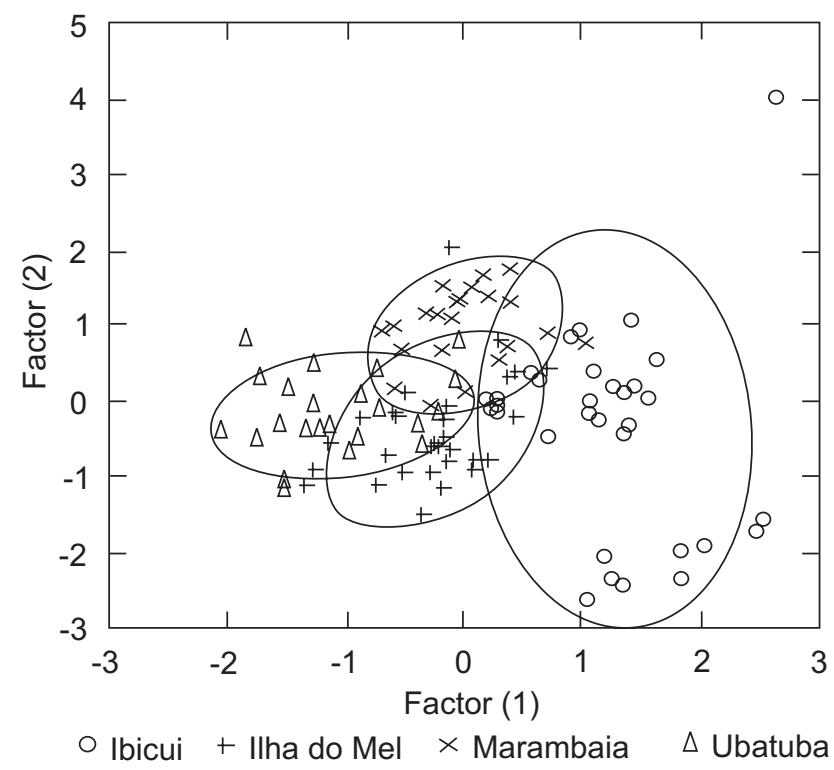

Figure 9. Principal Component Analysis (PCA) for sampled populations of $P$. Caudata.

Figure 10 shows the linear regression of length of first thoracic chaetiger and total size in $P$. caudata and the total length. The relationship is significant and positive (d.f. $=1, r=0.734$, $\mathrm{p}<0.001)$. Moreover, the relationship between the length of first 
thoracic chaetiger and the corresponding PC1 score were tested and found significant (d.f. $=1, \mathrm{r}=0.704, \mathrm{p}<0.001$ ), and corroborating its choice as a proxy for body length.

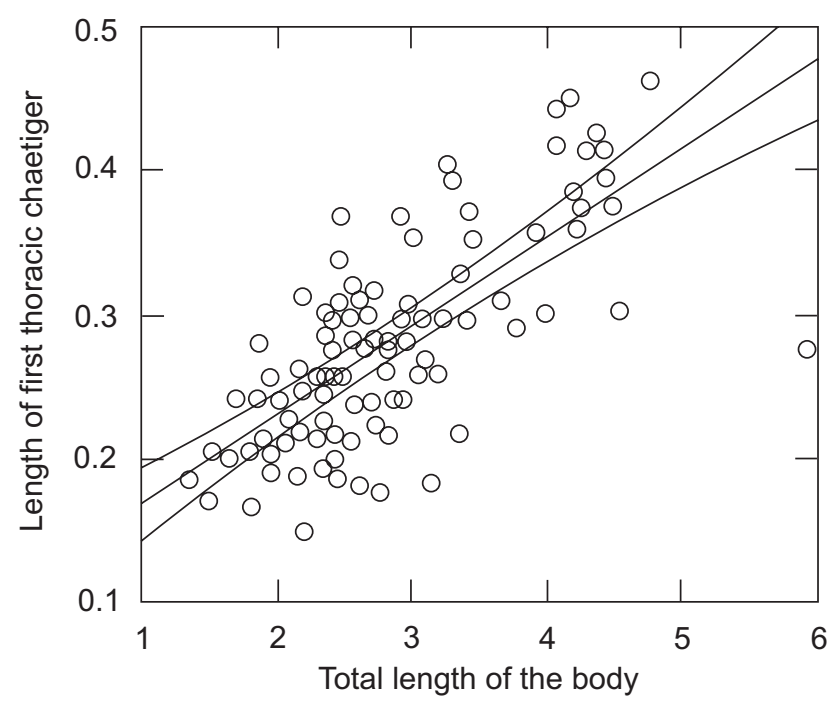

Figure 10. Linear regression of total length of the body and length of first thoracic chaetiger, calculated for the total sampled specimens of $P$. caudata.

\section{DISCUSSION}

The variable chosen as the best descriptor of total length of the body of $P$. caudata is the length of the first thoracic chaetiger. This conclusion was based on the results of the correlation analyses with the total length of the body, the low chance of rupture or deformation of the body during manipulation and fixation, the anterior position on the body of the animal and the scores obtained in the PCA.

Although the length of the abdominal and caudal appendage correlated strongly in all sampled populations, such structures presented low resistance to the collection, sorting and fixation processes. These parts are generally damaged, and therefore are not good descriptors of size. In a study of L. acuta, OMENA \& AMARAL (2001) have also recommended that posterior regions should not be used as morphometric parameters, as they can easily break during sampling and sorting processes.

Rigid body structures are often used to estimate polychaete size due to (1) their non-deformation quality during methodological procedures, (2) their great importance in studies on trophic relationships, and (3) because they are found in stomach content of predators (Chambers \& Milne 1975, Gillet 1990, FAUCHALD 1991). Nevertheless, in the present study, only the outer palea showed correlate significantly with body length for population 3 and 4, which were very low. A similar pattern was observed for the overall data with all populations. In addi-

Table II. Pearson's correlation coefficient of the variables calculated for each population of $P$. caudata. $\left(^{*}\right)$ Significant values at $\mathrm{p}>0.05$.

\begin{tabular}{|c|c|c|c|c|c|}
\hline \multirow{2}{*}{ Variable } & \multicolumn{4}{|c|}{ Population } & \multirow{2}{*}{ Total } \\
\hline & 1 & 2 & 3 & 4 & \\
\hline Length of thorax & 0.425 & $0.565^{*}$ & $0.805^{*}$ & 0.472 & $0.662^{*}$ \\
\hline Length of abdomen & $0.697^{*}$ & $0.937^{*}$ & $0.761^{*}$ & $0.900^{*}$ & $0.898^{*}$ \\
\hline Length of parathorax & 0.070 & 0.188 & $0.675^{*}$ & 0.372 & $0.653^{*}$ \\
\hline Caudal length & 0.473 & $0.701^{*}$ & $0.601^{*}$ & $0.750^{*}$ & $0.737^{*}$ \\
\hline Length of thoracic median setiger & 0.232 & -0.018 & 0.442 & 0.444 & $0.615^{*}$ \\
\hline Width of thoracic median setiger & 0.321 & 0.132 & 0.224 & 0.193 & -0.016 \\
\hline Length of first thoracic setiger & 0.502 & 0.395 & $0.630^{*}$ & $0.655^{\star}$ & $0.734^{*}$ \\
\hline Width of first thoracic setiger & 0.485 & 0.192 & 0.121 & 0.076 & 0.258 \\
\hline Length of first abdominal setiger & 0.181 & 0.195 & $0.695^{*}$ & $0.551^{*}$ & $0.681^{*}$ \\
\hline Width of first abdominal setiger & 0.472 & 0.031 & -0.062 & 0.182 & 0.214 \\
\hline Diameter of opercular crown 1 & 0.258 & 0.228 & 0.176 & 0.452 & $0.540^{*}$ \\
\hline Diameter of opercular crown 2 & 0.131 & 0.235 & 0.191 & 0.439 & $0.562^{*}$ \\
\hline Outer paleae & 0.310 & 0.029 & $0.581^{*}$ & $0.600^{*}$ & $0.696^{*}$ \\
\hline Middle paleae 1 & 0.213 & 0.287 & 0.387 & 0.356 & $0.618^{*}$ \\
\hline Middle paleae 2 & 0.294 & 0.388 & 0.482 & 0.447 & $0.525^{*}$ \\
\hline Inner paleae 1 & 0.168 & 0.274 & 0.349 & 0.195 & $0.670^{*}$ \\
\hline Inner paleae 2 & 0.060 & 0.130 & 0.403 & 0.114 & $0.569 *$ \\
\hline
\end{tabular}


Table III. Results from the first four components of the Principal Component Analysis (PCA), showing the scores of the measured variables for each of the component and their respective accumulated variance.

\begin{tabular}{|c|c|c|c|c|}
\hline \multirow{2}{*}{ Variables } & \multicolumn{4}{|c|}{ Components } \\
\hline & 1 & 2 & 3 & 4 \\
\hline Body length & 0.113 & 0.003 & -0.042 & 0.008 \\
\hline Length of thorax & 0.075 & 0.026 & 0.005 & -0.038 \\
\hline Length of abdomen & 0.141 & 0.004 & -0.071 & -0.014 \\
\hline Length of parathorax & 0.076 & -0.004 & 0.009 & -0.038 \\
\hline Caudal length & 0.111 & 0.036 & -0.020 & 0.076 \\
\hline Length of thoracic median setiger & 0.147 & -0.081 & 0.053 & -0.009 \\
\hline Width of thoracic median setiger & -0.009 & 0.125 & -0.021 & -0.044 \\
\hline Length of first thoracic setiger & 0.076 & -0.025 & -0.032 & -0.016 \\
\hline Width of first thoracic setiger & 0.049 & 0.040 & 0.071 & 0.004 \\
\hline Length of first abdominal setiger & 0.110 & -0.026 & -0.003 & -0.034 \\
\hline Width of first abdominal setiger & 0.039 & 0.054 & 0.048 & -0.017 \\
\hline Diameter of opercular crown 1 & 0.056 & 0.022 & 0.027 & 0.007 \\
\hline Diameter of opercular crown 2 & 0.054 & 0.017 & 0.024 & 0.010 \\
\hline Outer paleae & 0.043 & -0.001 & -0.004 & 0.002 \\
\hline Middle paleae 1 & 0.048 & 0.010 & 0.012 & 0.003 \\
\hline Middle paleae 2 & 0.079 & 0.054 & 0.007 & 0.036 \\
\hline Inner paleae 1 & 0.061 & -0.003 & 0.006 & 0.008 \\
\hline Inner paleae 2 & 0.053 & 0.010 & 0.023 & 0.007 \\
\hline Explained variation & 0.123 & 0.034 & 0.021 & 0.014 \\
\hline Total percentage of variation & 51.861 & 14.267 & 8.882 & 6.000 \\
\hline
\end{tabular}

tion, these structures require a long time to manipulate and to mount before the measurements can be obtained and suffer constant wearing by the activity of the animal in the tube.

Despite their frequent use by several authors (CARON et al. 1995, Omena \& Amaral 2001, Santos 1994, Sardá \& Martin 1993, SEITZ \& SCAFFNER 1995), width measurements did not correlate significantly with body length, both when populations were analyzed separately and in the combined dataset, and are not adequate for estimating the length of $P$. caudata.

Anterior regions have been used as good descriptors due to their rigidity. These structures in some species of polychaete do not deform when subject to the methodological procedures such as anaesthesia and fixation, thus allowing for rapid and simple manipulation. Costa-PAiva et al. (2007), in a study of Branchiomma luctuosum (Grube, 1869) showed that the length of first chaetiger does not present deformations when subject to different treatments of anaesthetization and fixation, suggesting a common pattern for the whole family Sabellidae and other families of the order Sabellida. Fauchald (1991) showed that, in the case of eunicid polychaetes, many of the anterior segments displayed high correlation with total length, and sug- gested the use of this measurement to estimate their size. RibeIro et al. (2001), in a morphometric study Armandia (Filippi, 1861), indicated that prostomium length was highly correlated to total length. Seitz \& Schaffner (1995) suggested use of the maximum width of the prostomium for L. medusa as a proxy for body length, given that this measurement had the highest correlation with dry weight. Costa-PaIva \& Paiva (2007) found that peristomium width and palp length were the most efficient variables for estimating body size in Eunice. In the present study, the thoracic length showed high coefficient for populations 2 and 3 and the length of the first thoracic chaetiger showed one of the highest correlations for population 4 as well as for the the combined dataset with all populations.

In a study on L. acuta, OMena \& Amaral (2001) detected a pattern that is expected in organisms that grow by means of increase of segments, such as polychaetes, namely to grow proportionally more in length than in weight. Furthermore, the same authors observed that the anterior portion of the body is the major contributor of the total weight compared to the remaining segments. In P. caudata, the first PC accounted for more than $50 \%$ of the variation in the dataset, which also dem- 
onstrate the existence of this pattern in the present species. Another important characteristic in the biology of sabelariids is, according to KirTley (1994), the ability to control the increase in the number of abdominal segments according to environmental limitations such as the lack of material to construct tubes. Consequently, body size could strongly influence the total size of this species. Although the amplitude of ontogenetic variation of the present data is unknown, results of the PCA suggest that the shape of the individual is of limited value to describe the intraspecific morphometric variation of the species when compared to size.

Given that populations showed significant morphometric differentiation, one cannot determine a single measure for estimating the length of $P$. caudata in all populations along the Brazilian coast. Alternatively, one of the estimated measures could be used, yet one must take into account the fact that the value may vary in different populations. In addition to being one of the variables with highest correlation to the total length in almost all populations, the length of the first thoracic chaetiger is easily obtained and suffer little deformation in many polychaetes. Considering these qualities, we suggest that this measurement can be safely used to monitor populations of $P$. caudata.

\section{ACKNOWLEDGEMENTS}

We thank Antonia C.Z. Amaral for providing the specimens from Project Biota Fapesp, Cinthya S. Gomes for the specimens from Paraná, Bruno Ramirez for the specimens from Ibicuí and Marambaia, André S. dos Santos for the photos and Leonardo Torres for the maps. We also thank Francisco Racca Filho (UFRRJ) for the use of the ocular micrometer. Finally, we thank Abílio S. Gomes (UFF) and Paulo C. de Paiva (UFRJ) for the revision and contribution to the manuscript.

\section{LITERATURE CITED}

Amaral, A.C.Z. 1987. Breve Caracterização de Phragmatopoma lapidosa Kinberg 1867 (Polychaeta, Sabellariidae). Revista Brasileira de Zoologia 3 (8): 471-474.

Amaral, A.C.Z.; E.F. Nonato \& M.A.V. Petti. 1994. Contribution of the polychaetous annelids to the diet of some Brazilian fishes. Memoires du Museum National D'histoire Naturelle, Serie A, Zoologia, 162: 331-337.

Caron, A.; M. Oliver; G. Desrosiers \& C. Retiere. 1995. Population dynamics of the polychaete Nephtys caeca in an intertidal estuarine environment (Quebes, Canada). Journal of the Marine Biological Association of the United Kingdom 75 (4): 871-884.

Chambers, M.R. \& H. Milne. 1975. Life cycle and production of Nereis diversicolor O. F. Muller in the Ythan Estuary, Scotland. Estuarine Coastal Marine Science 3: 133-144.

Costa-Paiva, E.M. \& P.C. Paiva. 2007. A morphometric analysis of Eunice Cuvier (Annelida, Polychaeta) species. Revista Brasileira de Zoologia 24 (2): 353-358.
Desrosiers, G.; B. Vincent; C. Retie're \& L. Boucher. 1988. Comparison de critères utilisables pour l'étude de la structure des populations du polychète Nereis virens (Sars). Canadian Journal of Zoology 66: 1454-1459.

Elstrott, J. \& D.J. Irschick. 2004. Evolutionary correlations among morphology, habitat use and clinging performance in Caribbean Anolis lizards. Biological Journal of the Linnean Society 83: 389-398.

FAUCHALD, K. 1991. A morphometric study of eunicid polychaetes from Belize, Western Caribbean Sea. Ophelia 5: 47-53.

França, F.G.R.; D.O. Mesquita; C.C. Nogueira \& A.F.B. Araújo. 2008. Phylogeny and Ecology Determine Morphological Structure in a Snake Assemblage in the Central Brazilian Cerrado. Copeia 1: 20-36.

Gillet, P. 1990. Biomasse, prodution et dinamique des populations de Nereis diversicolor (Annélide polychète) de l'estuaire de La Loire. Oceanologica Acta 13 (3): 361-371.

Humason, G.L. 1979. Animal tissue techniques. San Francisco, W.H. Freeman and Company, $4^{\text {th }}$ ed., 661p.

Kirtley, W.D. 1994. A Review and Taxonomic Revision of the Family Sabellariidae Johnson, 1865 (Annelida; Polychaeta). Florida, Sabecon Press Science Series 1, 223p.

KNox, G.A. 1977. The role of polychaetes in benthic soft bottom communities, p. 507-604. In: D.J ReISH \& K. FAUCHALD (Eds). Essays on Polychaetus annelids in memory of Olga Hartmam. Los Angeles, Allan Hancock Foundation, University of Southern California, 604p.

MacCord, F.S. \& C.Z. Amaral. 2005. Morphometric analyses of two species of Scolelepis (Polychaeta: Spionidae). Journal of the Marine Biological Association of the United Kingdom 85 (4): 829-834.

Omena, E.P. \& A.C.Z. Amaral. 2000. Population dynamics and secondary production of Laeonereis acuta (Treadwell, 1923) (Nereididae: Polychaeta). Bulletin of Marine Science 67: 421-431.

Omena, E.P. \& A.C.Z. Amaral. 2001. Morphometric study of the nereidid Laeonereis acuta (Annelida:Polychaeta). Journal of the Marine Biological Association of the United Kingdom 81 (3800): 1-4.

Ribeiro, Z.A.; A.C.S. Brasil \& T.C.M. Almeida. 2001. Estudo Morfométrico de Armandia cf agilis (andrews, 1891) (Polychaeta, Opheliidae): uma abordagem metodológica. Contribuições Avulsas Sobre a História Natural do Brasil, UFRRJ, 38: 1-5.

SAnToS, P.J.P. 1994. Population dynamics and production of Scolelepis gaucha (Polychaeta: Spionidae) on the sandy beaches of Southern Brazil. Marine Ecology Progress Series 110: 159165.

SARDÁ, R. \& D. Martin. 1993. Populations of Streblospio (Polychaeta: Spionidae) in temperate zones: demography and production. Journal of the Marine Biological Association of the United Kingdom 73: 769-784.

Seitz, R.D. \& L.C. Schaffner. 1995. Population ecology and 
secondary production of the polychaete Loimia medusa (Terebellidae). Marine Biology 121: 701-711.

SOKAL, R.R. \& F. J. RoHLF. 1995. Biometry - The Principles and Practice of Statistics in Biological Research. New York, W.H. Freeman and Company, $3^{\text {rd }}$ ed., 887p.

VIEIRA, S. 1991. Introdução à Bioestatística. Rio de Janeiro, Ed. Campus, 203p.

Yокоуама, H. 1988. Effects of temperature on the feeding activity and growth rate of the spionid polychaeta Paraprionospio sp. (form A). Journal of Experimental Marine Biology and Ecology 123: 41-60.

Zale, A.V. \& S.G. MerRifield. 1989. Species profiles: life histories and environmental requirements of coastal fishes and invertebrates (South Florida) - reef building tube worm. U.S. Fish Wildlife Service Biological Report 82 (11.115). U.S. Army Corps of Enginneers, TR EL 82(4) 12p.

Submitted: 25.XI.2008; Accepted: 06.XII.2009.

Editorial responsibility: Marcos Tavares 